\title{
LPG Cookstove Use and Fuel Subsidies in the Cuzco Region of Peru
}

\author{
James Keese*, Carolina Guzman Vazquez, Maya O’Brien, Brooke Richter
}

Social Sciences Department, Cal Poly State University, San Luis Obispo, USA

Email address:

jkeese@calpoly.edu (J. Keese)

${ }^{*}$ Corresponding author

\section{To cite this article:}

James Keese, Carolina Guzman Vazquez, Maya O'Brien, Brooke Richter. LPG Cookstove Use and Fuel Subsidies in the Cuzco Region of Peru. International Journal of Sustainable Development Research. Vol. 6, No. 1, 2020, pp. 14-21. doi: 10.11648/j.ijsdr.20200601.13

Received: March 24, 2020; Accepted: April 9, 2020; Published: April 23, 2020

\begin{abstract}
: 2.8 billion people around the globe continue to use open fires and biomass stoves for cooking and heating. Household air pollution is a serious health hazard, especially for women and children. A solution involves promoting so-called clean fuels such as liquefied petroleum gas (LPG). The purpose of this research is to examine the use of LPG cookstoves in the Cuzco Region of Peru. A specific focus is on the Peruvian government's FISE gas subsidy program. Surveys were administered to seventy-seven households in four indigenous agriculturalist communities over two different years. The results show the widespread use of gas stoves, but only as a supplement to wood and other biomass. We concluded that FISE is well organized, easy to use, and properly targets low income households. However, while the LPG subsidy program does promote the use of some gas, it is insufficient to prompt a complete fuel switch given current prices and resource availability. This research critiques the energy ladder model for fuel switching, and the results reveal that the use of multiple fuels, or fuel stacking, continues to be the norm. Furthermore, the data suggest an increase in eucalyptus and pine reforestation efforts, which will impact the relative scarcity of fuels, fuel choice, and health in the rural areas of the Cuzco Region.
\end{abstract}

Keywords: LPG Cookstoves, Household Air Pollution, Fuel Subsidies, Peru

\section{Introduction}

Approximately 2.8 billion people, primarily in rural areas in developing countries, still rely on biomass fuels for cooking and heating [1]. The use of open cookfires in poorly vented dwellings, and the damage to health by the resulting household air pollution, has been well documented [2-4]. These problems are widespread and complex, and a multitude of technologies have been proposed as solutions. However, they generally involve either making the "available clean" (promoting improved biomass cookstoves) or making the "clean available" (switching to cleaner burning fuels) [5]. Improved biomass cookstoves still burn traditional fuels such as wood, dung, or agricultural residues, but are engineered to be more efficient and/or vent the smoke. Purported benefits include improved health, less deforestation, and reduced climate forcing emissions $[6,7]$. However, stove types, efficiencies, and rates of sustained use vary widely [8-11]. Furthermore, multiple studies and field trials have concluded that some of the stated health benefits are modest or minimal [5, 12-14], and most models fail to reduce household air pollution to international standards for the small particles of soot $\left(\mathrm{PM}_{2.5}\right)$ that penetrate deeply into the lungs.

The alternative to biomass fuels are the clean fuels which include electricity, LPG (liquefied petroleum gas), and biofuels (biogas and ethanol). Clean fuels offer greater benefits to health and address the environmental impacts of biomass fuels [14]. In Latin America, LPG is already widely available for cooking, especially in urban areas [15]. LPG is clean burning (no smoke), fuel-efficient, easy to use, and portable. It also emits less climate pollutants than biomass or other fossil fuels $[16,17]$. However, people living in poverty may not have the money to purchase LPG. The other commonly available clean fuel is electricity. While poor communities are increasingly connected to the electric power grids, electricity has traditionally been considered too expensive for cooking [5, 18]. Troncoso and Soares [17] concluded that price is the most important barrier to the adoption of LPG. They added that in Latin America, government LPG fuel subsidy programs have been an 
effective strategy to improve access to this clean fuel. Subsidies generally take the form of cash payments or vouchers for tanks of LPG. However, complicating access, in rural communities biomass usually continues to be available locally and is free if gathered. Therefore, the amount and effectiveness of the subsidy is influenced by the availability and price of other resources. Finally, political pressure may result in subsidies being extended to the middle and upper classes. But in order to be fiscally sustainable, the programs must be targeted toward the poorest populations [16, 17].

Energy choice or household fuel switching has been conceptualized by the energy ladder model [4, 19, 20]. Movement up the ladder is characterized by a linear switch from primitive fuels such a wood, animal dung or crop residues, to transition fuels such as charcoal, kerosene or coal, and finally to the more efficient and cleaner-burning

Energy Ladder Model advanced fuels such as electricity, LPG or biofuels (Figure 1). When measuring emissions from household air pollution, LPG is the target or standard by which other cooking fuels are compared [4]. The energy ladder is an income-based model. As a household's income rises, it moves up the rungs of the ladder with exclusive switches, abandoning one fuel for another. However, field observations have shown that multiple fuel use is the more common practice [9, 21, 22]. Households adopt fuels that are partial substitutes rather than perfect substitutes. The use of two or more fuels is referred to as energy or fuel "stacking" (Figure 1). Many factors, not just income, determine fuel choice, including price, availability, policy, local understanding of health risks, urban/rural location, cultural preferences, and tradition. Energy serves multiple needs and overlapping uses, all of which take place in a household and a community $[16,17,20]$.

Energy or Fuel Stacking

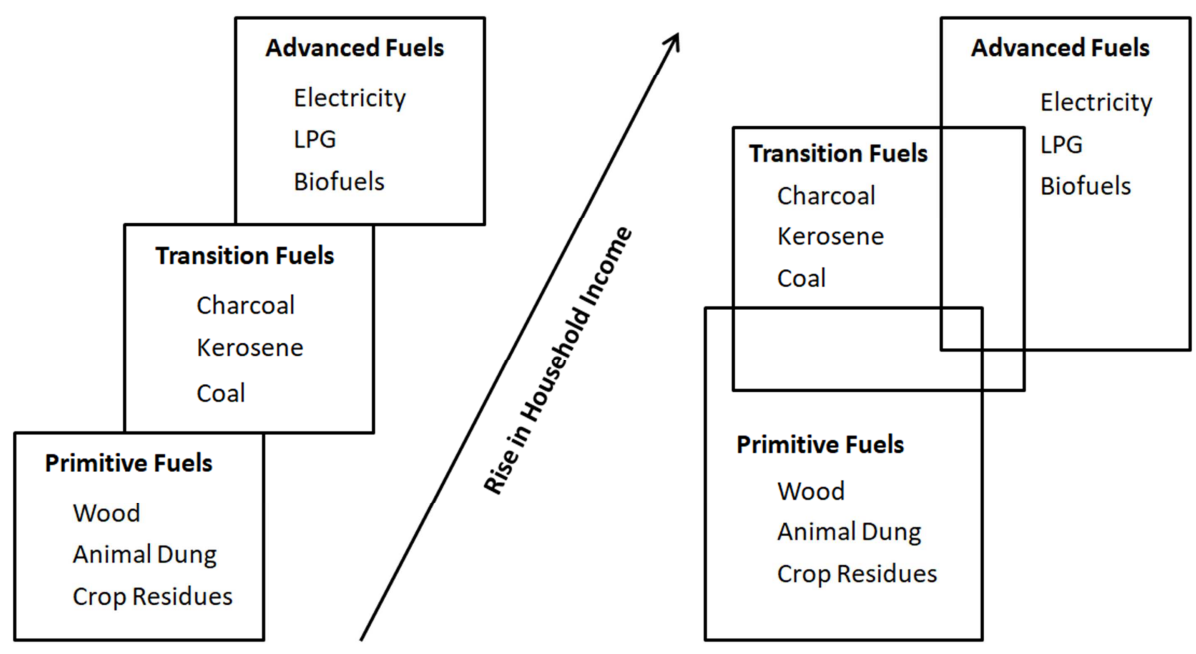

Figure 1. Energy choice or household fuel switching [19].

The purpose of this research is to examine the use of LPG cookstoves in rural areas of the Cuzco Region of Peru. A specific focus is on the role that the Peruvian government's LPG subsidy program plays in the use of gas stoves. This research sought to answer the following questions. What is the rate of adoption of LPG for cooking? How and under what conditions is LPG used? And, is the subsidy program effective in promoting a switch to LPG? Surveys were administered to seventy-seven households in four indigenous agriculturalist communities. Additional field research specific to gas stoves was conducted after the completion of a separate study on the introduction of improved biomass stoves [18]. Therefore, we were able to learn about gas stoves within the larger cultural context of a cooking system that included multiple stoves, fuels, and development interventions.

\section{FISE LPG Fuel Subsidy Program}

In 2012, the Peruvian government created the FISE program (Fondo de Inclusión Social Energético or Social
Fund for Energy Inclusion). Administered by the Ministry of Energy and Mines, the principal goals of FISE are to expand the use of natural gas and to make domestic LPG accessible to poor populations, in both rural and urban areas [23]. According to FISE [23], LPG is important in reducing the use of dirty fuels such as firewood, manure, and crop residues that are damaging to health (particularly for women, girls, and small children). Cooking with gas also reduces the time dedicated to collecting wood and other fuels, which could allow more time for children to study and for women to work. FISE equates the use of LPG with poverty reduction and socioeconomic development, contributing to improvements in health, education, gender equality, and environmental sustainability.

FISE is a targeted subsidy program. To qualify, families and communities must be registered as poor or extremely poor as determined by the national census and by household inspections. Also, a family may not consume more than 30 $\mathrm{kWh}$ (kilowatt hours) of electricity per month (costing about 18 Soles or US\$5.50) averaged over the past twelve months. Additionally, families with homes made of brick or cement 
do not qualify, as that is an indicator of higher incomes [24]. Tanks of LPG are distributed using a voucher system. Recipients receive one voucher per month which allows them to buy a $10 \mathrm{~kg}$ tank of LPG for 16 Peruvian Soles (US\$5), or half the market price [25] In the Cuzco Region, FISE is administered by Electro Sureste, which is a regional division of the state electricity company. Vouchers are either physically attached to the paper receipt for the monthly electricity bill or can be received electronically via cell phone. Recipients exchange vouchers for a tank of gas at an authorized distributor, of which there are more than 4,000 nationally [23]. Many rural communities have a local distributor. If not, they receive deliveries by truck or motorcycle, or tanks are available in nearby market towns (Figure 2). With broad access to cellular service in Peru, customers can also order by phone. In 2018, there were 135,176 recipients of vouchers in the Cuzco Region [26].

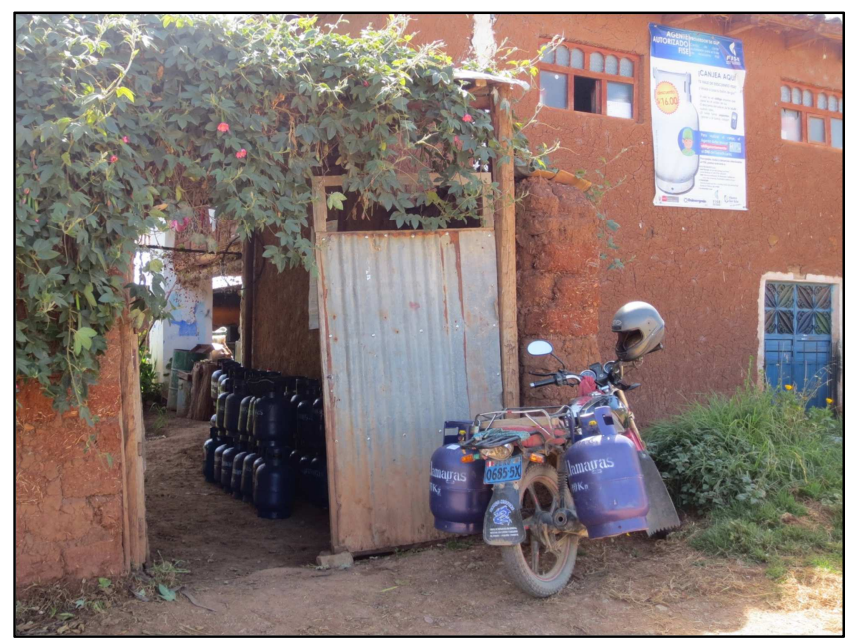

Figure 2. Authorized LPG distributor in the community of Chakan (Photo by author).
Recipients of FISE are also required to have a gas stove. Until 2017, FISE provided gas stoves at no cost to families who did not have one. However, that aspect of the program was discontinued because gas stoves are affordable and widely available for purchase in Cuzco and other local urban centers. The price of a small two-burner gas stove ranges from 50-150 soles (US\$15.50-US\$46.50), which includes stoves of many qualities and models manufactured domestically and abroad. In the case of Peru, gas stoves are being provided by the market. Horgque [24] stated that people who want to cook with gas will buy a stove, and our data support that claim.

\section{Study Site}

With a per capita income of US\$13,810 [27], Peru is a middle-income county. However, there is significant inequality and poverty, both socially and regionally, which is concentrated among the indigenous, rural, and urban poor populations. The poverty rate in Peru in 2017 was 21.7 percent [28]. The Peruvian government defines poverty as a monthly income of less than 338 Soles (US\$105) per person, and extreme poverty as less than 183 Soles (US\$57). An estimated 7.3 million people, about one-quarter of the national population, lack access to clean domestic fuels, relying primarily on firewood and dung [25, 29]. Wood (and other biomass) is the dominant cooking fuel in rural areas, accounting for three-quarters of use. In sharp contrast, gas is used for over 70 percent of cooking needs in urban places. Funded largely by NGOs and bilateral government aid, improved cookstove programs in Peru date back to the 1980s. Recognizing the problems associated with cooking and fuels, in 2009, the Peruvian government launched a national effort to coordinate the development and distribution of both improved biomass stoves and gas stoves [15].

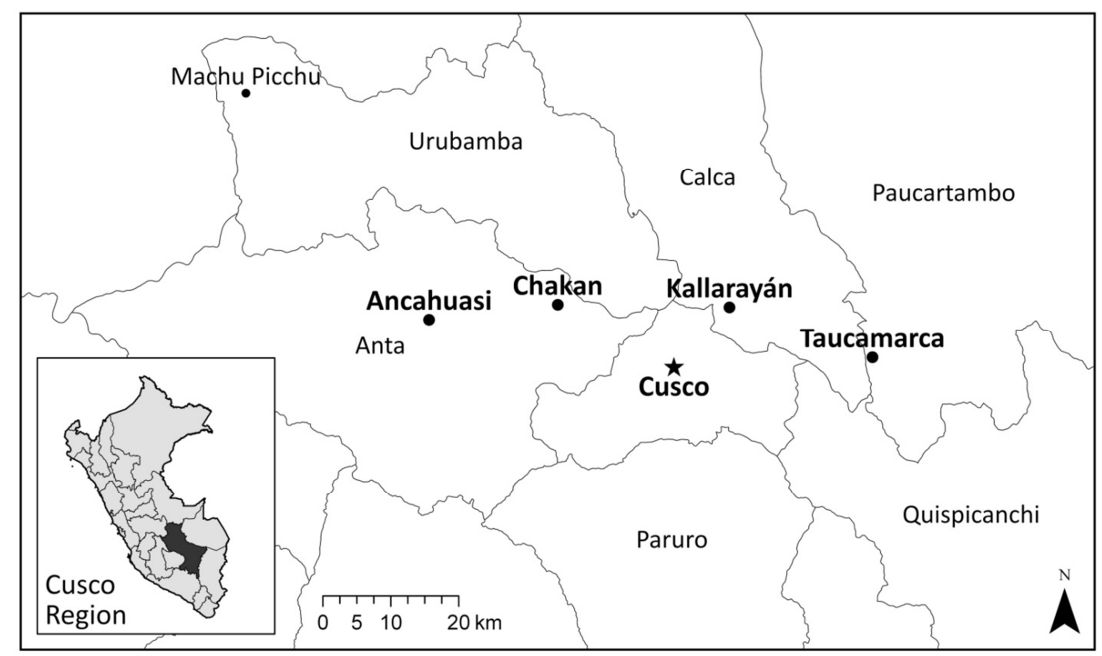

Figure 3. Study Communities near Cusco (Map by author).

Peru is divided into regions, provinces, and districts. The study sites are located in the Andean highlands of the Cuzco Region. (Regions are analogous to states in the USA.) The four communities included in this study are Ancahuasi
(Anta Province), Kallarayán (Calca Province), Chakan (Anta Province), and Taucamarca (Paucartambo province) (Figure 3). The people are indigenous and speak Quechua as their first language. (Twenty-six percent of Peru's 
population is indigenous [30].) Subsistence smallholder agriculture and livestock-raising continue to be the predominant economic activities. Families typically live in houses built using mud/adobe bricks, with a ground floor room used for a kitchen. The traditional biomass stove (called a fogón) is made with three large adobe bricks arranged in a u-shape. Pots sit on the bricks over an open fire, and when a fire is lit, the poorly ventilated houses fill with smoke exposing the residents to the hazards of household air pollution.

\section{Methodology}

Data were gathered from seventy-seven households in the four communities during two site visits to Peru. The communities were selected because they were project sites for an improved biomass cookstove project carried out by ProPeru Service Corps. ProPeru is a volunteer-abroad NGO based in Cuzco. In March of 2015, a three-week trip was made to conduct a follow-up study on the improved biomass cookstove project [18]. (Briefly summarized, the results indicated that 70 percent of the stoves were still in use as the primary cooking device. The study also identified characteristics of that stove which accounted for the higher than expected rate of sustained use.) Surveys were administered to forty-one households in the three communities where volunteers had installed stoves during the previous three years. While that research focused on the biomass stove, we included questions on gas stoves, electricity, wood use, household air pollution, and health. In April of 2018, additional data specific to this paper were gathered in a fourth project community. Thirty-six surveys were administered in all of the households at the time their ProPeru improved biomass stove was being installed. The second survey included additional questions on the use of LPG stoves and the FISE subsidy program. In 2018, information was also gathered through visits to the FISE office of Electro Sureste and shops that sell gas stoves in the area near the San Pedro market in Cuzco. The results presented in this paper are based on the new survey data obtained in the fourth community in 2018, on previously unpublished data from the 2015 survey, and on aggregate data from both years.

\section{Results}

Locally, the people understood the health risks associated with household air pollution. Ninety-eight percent of the people surveyed stated that smoke in the house bothered them and was damaging to their health. People reported that smoke hurts their eyes, lungs, throat, nose, heart, and brain. There is widespread awareness of these problems because public health workers in Peru are talking about this issue when people visit a clinic. Also, multiple respondents mentioned that family members had had illnesses attributed to exposure to smoke. It bothers them and they are increasingly aware of the risks it poses. Because smoke impacts people in noticeable ways on a daily basis, there is an opening for the introduction of new stove technologies and fuel switching.

Eighty-one percent of the households surveyed in the four communities had gas stoves, indicating widespread diffusion of this fuel and technology (Table 1). However, we learned that gas is used primarily as a supplement to biomass, not as the main cooking fuel. Gas is an emergency fuel. It is used when wood or other biomass is not available, but especially during the rainy season when wood gets wet. People also reported using gas as a fuel of convenience. The gas stove is utilized when people are in a hurry. It is easy to light and can cook something rapidly. This is especially important in the morning to get the children off to school or at night when people cook small amounts or reheat food after a work day. People reported preparing items such as coffee, tea, soup, porridge (oats, quinoa, wheat), rice, fava beans, potatoes, corn, pasta, and eggs. Nevertheless, an additional question in the 2018 survey revealed that only one-quarter of the households used their gas stoves every day, but even in those cases, only as a supplement to biomass (Figure 4).

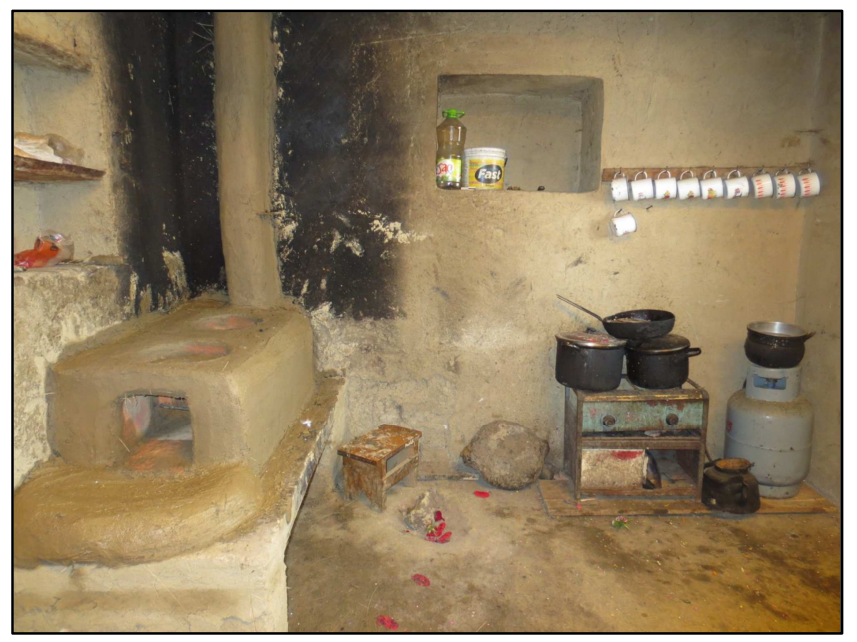

Figure 4. House in Taucamarca with the ProPeru improved biomass stove (left) and a typical gas stove (right) (Photo by author).

Table 1. Summary of survey results.

\begin{tabular}{|c|c|c|c|c|c|c|c|c|}
\hline No & $\begin{array}{l}\text { Community } \\
\text { name }\end{array}$ & \# of surveys & $\%$ Using LPG & $\begin{array}{l}\text { Access to } \\
\text { electricity }\end{array}$ & $\begin{array}{l}\% \text { Burning } \\
\text { wood }\end{array}$ & $\begin{array}{l}\% \text { Burning } \\
\text { other biomass }\end{array}$ & $\begin{array}{l}\% \text { Growing } \\
\text { trees }\end{array}$ & $\begin{array}{l}\text { \% Enrolled in } \\
\text { FISE }^{\text {b }}\end{array}$ \\
\hline 1 & Ancahuasi & 10 & 80 & Yes & 100 & 80 & 10 & $\mathrm{n} / \mathrm{a}$ \\
\hline 2 & Kallarayán & 16 & 75 & Yes & 100 & 88 & 56 & $\mathrm{n} / \mathrm{a}$ \\
\hline 3 & Chakan & 15 & 80 & Yes & 100 & 100 & 13 & $\mathrm{n} / \mathrm{a}$ \\
\hline \multirow[t]{2}{*}{4} & Taucamarca & 36 & 83 & Yes & 100 & 75 & 72 & 56 \\
\hline & Total & 77 & $81 \%$ & $100 \%$ & $100 \%$ & $83 \%$ & $51 \%$ & $\mathrm{n} / \mathrm{a}$ \\
\hline
\end{tabular}

${ }^{a}$ Percentage includes households that burn animal dung and/or crop residues.

${ }^{\mathrm{b}}$ Data on FISE was only collected in the 2018 survey in the community of Taucamarca. 
The main reason people do not use gas exclusively, or as their primary fuel, has to do with price. Therefore, subsidy programs are intended to help poor households overcome this barrier to fuel switching. In the 2018 survey, the reported cost of a tank of LPG ranged from the subsidized price of 16-17 soles (about US\$5) to the market price of 33-34 soles (about US\$10). In Taucamarca, twenty of the thirty-six families (56 percent) were enrolled in the FISE subsidy program. Based on the responses and observations, non-participating families had not yet enrolled or were too affluent to qualify. Not only was affluence judged by the quality of their home construction, but also by the number of livestock they owned (which is the principal source of income from agriculture), or the ownership of a vehicle. When asked what they liked about FISE, 90 percent of the respondents indicated that the tank was cheaper, thus saving them money. The primary benefit or motivation for participating in FISE was economic or price-related. There was no indication that the program was difficult to use. The vouchers came attached to the electricity bill receipt and LPG tanks were available from local distributors or in the market towns where people visit regularly. The limited criticisms related mostly to not getting enough gas to last the full month until they could get another voucher.

When cooking exclusively with gas, people reported that a tank lasts between ten to twenty days. Once the gas runs out, then the families with FISE waited until the end of the month to receive the next voucher to get a new tank. In the meantime, they cooked only with their wood/biomass stoves. Therefore, our data show that two or three tanks of LPG are necessary to cover all cooking needs for a month. This indicates two issues. One, there is an economic barrier to the exclusive use of gas. Two, the support provided by the FISE subsidy program is inadequate to overcome this barrier. However, Horgque [24] stated that it was not a priority of FISE to promote the full conversion to gas stoves for cooking. FISE is a "trial" program. It lets people get used to gas, to see if they like it. It is a means of changing traditional culture. However, contrary to this assertion, people in the study communities are using LPG for cooking, whether they are enrolled in FISE or not.

The concept of relative scarcity also plays a role in fuel choice. The price and/or accessibility of one fuel may have an impact on the use of another [31]. In response to the need for wood, many households (and communities) in the region are growing trees, mostly eucalyptus. Eucalyptus has been grown widely throughout the region since the 1960 s, and was initially promoted by government incentives [32]. The people prefer it because it grows quickly, self-propagates after cutting, and burns easily. In the 2015 survey, thirty-two percent of the households had planted trees. In the 2018 survey, seventy-two percent of the households reported having trees. In addition, a 2019 pilot study on tree cultivation in community 3 found that six of eight households surveyed had planted eucalyptus. The more recent data suggest that eucalyptus cultivation is expanding in the region, both for household use and as a potential source of income. It is common for a family to have twenty to fifty trees on or around the margins of their land. However, of the thirty-six families reporting the number of trees they owned, forty-four percent said they had more than 100 trees, and twenty-two percent had more than 500 trees. Much of the land in the study communities is marginal, characterized by steep slopes and rocky soils. Agriculture is hindered by low productivity and provides limited opportunities for cash income. However, eucalyptus trees will grow on the marginal plots (Figure 5). The results highlighted the utility of using the marginal lands for fuel and income-producing tree farming instead of low productivity subsistence agriculture. With respect to cooking fuels, an increase in tree planting suggests that the availability of wood in the rural areas of the Cuzco Region could be increasing, and thus will remain relatively more abundant or cheaper than gas.

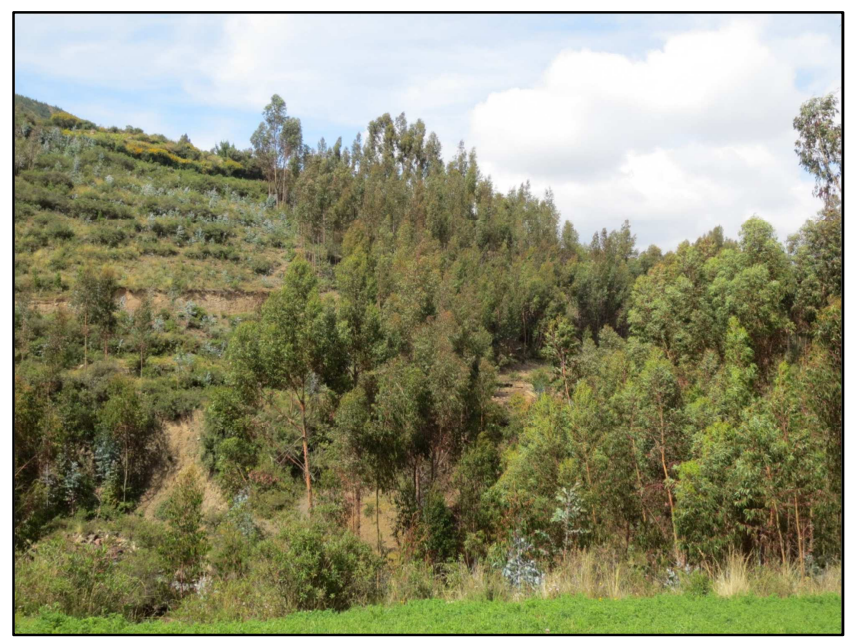

Figure 5. Eucalyptus trees in the community of Taucamarca (Photo by author).

The other clean fuel is electricity. All four study communities were connected to the grid, and ninety-nine percent of the households in our survey were metered and had service. While Electro Sureste administers FISE and the monthly bill is the mechanism to distribute LPG vouchers, it does not promote electricity for cooking. To the contrary, enrollment in FISE requires low electricity use. Electricity is not used for cooking, but only for lighting and charging cell phones, and sometimes for radios or TVs. Monthly bills were all below 19 soles (US\$6), and everyone said that electricity was expensive. FISE does aid families with their electric bills, but this benefit was very limited and not offered to the study communities. Therefore, under current market and policy conditions, electricity does not appear to be a cleanfuel option for cooking for the poor in Peru.

In addition to price and relative scarcity, this research also identified a non-cooking use of a stove as a critical factor affecting fuel choice. In addition to cooking, a biomass stove (traditional or ProPeru improved) also heats the room. The coals and heated bricks stay warm long after the stove is used 
for cooking. In the Andean zone of the Cuzco Region, temperatures at night drop into the 30 s ( 2 to 4 degrees Celsius) during the winter months of June, July, and August. Houses are not insulated and get extremely cold. People are using their wood-burning stoves for home heating. A small two-burner gas stove serves no heating function. By not heating the house, it fails to meet this essential need. In the first survey, we did learn and report that biomass stoves provided home heating. However, in the second survey we were able to identify this issue as a barrier to the adoption of gas stoves.

In the end, biomass continues to be the fuel that supports the study communities. One hundred percent of respondents reported burning wood in their homes. Sixty-nine percent of those interviewed said they burned animal dung (cow, sheep, guinea pig), and sixty-two percent burned crop residues. A total of eighty-three percent burned one, the other, or both (see Table 1). This form of energy or fuel stacking pre-dates the introduction of so-called modern stoves or clean fuels and continues to be an important feature of the regional context. In places where people practice subsistence agriculture, have limited cash incomes, and are poor, it is likely that this practice will remain dominant until the economics of resource and fuel availability significantly change.

\section{Conclusion}

The purpose of this research was to examine the use of LPG cookstoves in the Cuzco region of Peru, with a specific focus on the government's FISE LPG subsidy program. We sought to answer three questions. What is the rate of adoption of LPG for cooking? How and under what conditions is LPG used? And, is the subsidy program effective in promoting a switch to LPG? The results showed that LPG is being widely adopted. Eighty-one percent of the households surveyed in the four study communities were using gas stoves for cooking. However, LPG serves as an emergency fuel and a fuel of convenience. It remains a supplement to wood and other biomass. We determined that the most important impediment to fuel switching is price. LPG subsidies, such as Peru's FISE program, are designed to help people who are poor to overcome this economic barrier. Our research concluded that FISE is well organized, easy to use, and properly targets low income households. The program provides one $10 \mathrm{~kg}$ tank of gas per month, and tanks are widely available from local distributors. However, we learned that people need two or three tanks per month to cook exclusively with gas. Therefore, the subsidy is inadequate to overcome the price barrier to a complete conversion from biomass to LPG.

FISE's actual monthly subsidy per enrolled household is 16 soles (US\$5), or half the market price of 32 soles (US\$10) for one tank of LPG. Our data suggest that the 50 percent subsidy is sufficient to encourage people to purchase one tank. But, taking into account that people need two or three tanks if they want to use gas as their primary cooking fuel, then the effective subsidy rate would drop to 33 percent or 20 percent (when divided by the total cost of two or three tanks). The amount of the subsidy does not provide a sufficient incentive to encourage people to purchase more than one tank. The FISE program clearly promotes some use of gas, but not its exclusive use. While that is not the goal of the program, it needs to be if the Peruvian government is committed to addressing household air pollution. To make that possible, and to appropriately serve its targeted population in rural areas, FISE would need to extend the 50 percent subsidy to include up to two additional tanks of LPG.

FISE does extend access, though in a limited way, to LPG in Peru. However, it might actually inhibit access to the other locally-available clean fuel, electricity. One of the criterion for inclusion in the program, which is used as an indicator of poverty, is that a household is not eligible if the consumption of electricity is more than $30 \mathrm{kWh}$ per month. The average per capita use of electricity in Peru is $112 \mathrm{kWh}$ per month [33], or almost four times the limit imposed by FISE. This household-level requirement may discourage the use of electricity for cooking (which has potential health benefits), food refrigeration (of which we did not view in any household), or other productive activities. In this way, FISE might be encouraging energy poverty.

Our research also validated the importance of understanding the context in which stoves and programs are situated. Many factors influence the decision to adopt a stove technology. In rural Cuzco, despite the reported scarcity, wood continues to be free or available at a very low cost to most families. In the context of free biomass, the current energy subsidy is not high enough to induce a fuel switch. As long as the accessibility or cost of biomass is "cheaper" relative to gas, it will remain the primary fuel. We also noted that in highland Peru a stove often serves multiple needs. It has to cook food efficiently and appropriately, and it may have to heat the house. In reference to improved biomass cookstoves, Sesan [11] concluded that the best performing stove in a lab test might not be the one that the people prefer in the field. By analogy, even if a fuel is cleaner, we cannot assume that people will use it. In the study communities, a combination of reasons that are technical, economic, political, and cultural explains why biomass continues to be more widely used than gas. The consequence is that the poorest households will continue to have limited access to affordable LPG and the corresponding benefits to health. Gas will remain a secondary fuel until one or more conditions change; the subsidy is increased, the market price of gas decreases, wood becomes more costly, or cash incomes rise. This research also helps to understand the difference in LPG use between urban and rural households in Peru. While the subsidy is the same in both places, gas is used for most cooking needs in cities because people have to purchase wood and because income is predominantly in the form of cash.

Almost all of the households in our study had three cooking devices - the traditional fogón stove, an improved biomass cookstove, and a gas stove. In terms of fuels, every community was using biomass (wood, manure, and crop 
residues), LPG, and electricity (though not for cooking). The dominant feature that describes energy use in the study communities is stacking. Partial conversion is the norm. Therefore, the energy ladder model that predicts mutually exclusive fuel choices is not supported by our field research. Within this context, a policy that focuses solely on fuel switching from biomass to gas would be ill-advised and counterproductive. As long as people in the Cuzco region (or similar areas) continue to rely on biomass, there will also be a need for improved biomass cookstoves, despite their mixed results. At this time, our research suggests that dual efforts to facilitate access to both cleaner stoves and clean fuels continue to be needed. This combined strategy will address more of the issues associated with cookstoves, specifically as they relate to household air pollution and health, women and children, and environmental sustainability.

\section{Acknowledgements}

This research was supported by the Cal Poly Latin American Studies Program and the Cal Poly College of Liberal Arts. The authors wish to thank Benjamin FunstonTimms for his helpful comments.

\section{References}

[1] WHO (World Health Organization). (2018, May 8). Household air pollution and health. Retrieved from http://www.who.int/news-room/fact-sheets/detail/householdair-pollution-and-health.

[2] N. Bruce, R. Perez-Padilla and R. Albalak (2000). "Indoor air pollution in developing countries: A major environmental and public health challenge," Bulletin of the World Health Organization 78 (9), 1078-1092.

[3] H. Warwick and A. Doig (2004). "Smoke: The Killer in the Kitchen", London: ITDG Publishing.

[4] K. R. Smith (2006). Health impacts of household fuelwood use in developing countries. Unasylva, 57, 41-44.

[5] K. R. Smith and A. Sagar (2014). Making the clean available: Escaping India's Chulha Trap. Energy Policy, 75, 410-414.

[6] M. Agurto Adrianzén (2013). Improved cooking stoves and firewood consumption: Quasi-experimental evidence from the northern Peruvian Andes. Ecological Economics, 89, 135-143.

[7] T. Urmee and S. Gyamfi (2014). A review of improved cookstove technologies and programs. Renewable and Sustainable Energy Reviews, 33, 625-635.

[8] K. Pine, R. Edwards, O. Masera, A. Schilmann, A. MarrónMares, and H. Rojas-Rodríguez (2011). Adoption and use of improved biomass stoves in rural Mexico. Energy and Sustainable Development, 15, 176-183.

[9] L. Ruiz-Mercado, O. Masera, H. Zamora, and K. R. Smith (2011). Adoption and sustained use of improved cookstoves. Energy Policy, 39, 7557-7566.

[10] C. Bielecki and G. Wingenbach (2014). Rethinking improved cookstove diffusion programs: A case study of social perceptions and cooking choices in rural Guatemala. Energy Policy, 66, 350-358.

[11] T. Sesan (2014). Global Imperatives, local contingencies: An analysis of divergent priorities and dominant perspectives in stove development from the 1970 s to date. Progress in Development Studies, 14 (1), 3-20.

[12] K. R. Smith, J. P. McCracken, M. W. Weber, A. Hubbard, AJenny, L. M. Thompson, J. Balmes, A. Diaz, B. Arana, and N. Bruce (2011). Effect of reduction in household air pollution on childhood pneumonia in Guatemala (RESPIRE): a randomised controlled trial. Lancet, 378 (9804), 17171726.

[13] K. Mortimer, C. B., Ndamala, A. W.., Naunje, J. Malava, C. Katundu, W. Weston, D. Havens, D. Pope, N. G. Bruce, M. Nyirenda, D. Wang, A. Crampin, J. Grigg, J. Balmes, and S. B. Gordon, S. B. (2017). A cleaner burning biomass-fuelled cookstove intervention to prevent pneumonia in children under 5 years old in rural Malawi (the Cooking and Pneumonia Study): a cluster randomised controlled trial. Lancet, 389, 167-175.

[14] J. Rosenthal, A. Quinn, A. P. Grieshop, A. Pillarisetti, and R. I. Glass (2018). Clean cooking and the SDGs: Integrated analytical approaches to guide energy interventions for health and environment goals. Energy for Sustainable Development, $42,152-159$.

[15] ADP (Accenture Development Partnerships). (2012). Global alliance for clean cookstoves: Peru market assessment sector mapping. Retrieved from http://cleancookstoves.org/resources_files/peru-marketassessment-sector-mapping.pdf.

[16] M. Kojima, R. Bacon and Z. Zhou (2011). Who uses bottled gas? Evidence from households in developing countries. The World Bank Policy Research Working Paper 5731.

[17] K. Troncoso, A. Soares da Silva (2017). LPG fuel subsidies in Latin America and the use of solid fuels to cook. Energy Policy, 107, 188-196.

[18] J. Keese, A. Camacho, and A. Chavez (2017). Follow-up study of improved cookstoves in the Cuzco region of Peru. Development in Practice, 27 (1), 26-36. DOI: 10.1080/09614524.2017.1257565.

[19] N. Schlag and F. Zuzarte (2008). Market Barriers to Clean Cooking Fuels in Sub-Saharan Africa: A Literature Review (An SEI Working Paper). Stockholm Environment Institute.

[20] B. Van der Kroon, B., Brouwer and P. Van Beukering (2013). The energy ladder: Theoretical myth or empirical truth? Results from a met-analysis. Renewable and Sustainable Energy Reviews, 20, 504-513.

[21] J. Calzada and A. Sanz (2018). Universal access to clean cookstoves: Evaluation of a public program in Peru. Energy Policy, 118, 559-572.

[22] C. Gould. and J. Urpelainen (2018). LPG as a clean cooking fuel: Adoption, use, and impact in rural India. Energy Policy, $66,395-408$.

[23] FISE (Fondo de Inclusión Social Energético). (2018a). Gas doméstico. Retrieved from http://www.fise.gob.pe/

[24] Horgque, J. C. (2018). Supervisor, Fondo de Inclusión Social Energético (FISE). Personal communication. Cuzco, Peru. 
[25] APEC (Asia-Pacific Economic Cooperation) (2015). Peer Review on Fossil Fuel Subsidy Reforms in Peru, Final Report. Nathan Associates Inc. for the US-APEC Technical Assistance to Advance Regional Integration Project.

[26] FISE (Fondo de Inclusión Social Energético) (2018b). Informe del Program FISE Marzo 2018. Cuzco, Peru: FISE.

[27] World Bank (2019a). Gross national income per capita 2018, atlas method and ppp. Retrieved from https://databank.worldbank.org/data/download/GNIPC.pdf.

[28] INEI (Instituto Nacional de Estadística Informática). (2018). Pobreza monetaria afectó al $21,7 \%$ de la población del país durante el año 2017. Retrieved from https://www.inei.gob.pe/prensa/noticias/pobreza-monetariaafecto-al-217-de-la-poblacion-del-pais-durante-el-ano-2017$10711 /$.

[29] Microsol. (2017). Improved Cookstove Benefits. Retrieved from www.microsol-int.com/microsol.
[30] CIA (Central Intelligence Agency). (2019). The World Factbook. Retrieved from https://www.cia.gov/library/publications/the-worldfactbook/geos/pe.html.

[31] T. Takama, S. Tsephel, and F. X. Johnson (2012). Evaluating the relative strength of product-specific factors in fuel switching and stove choice decisions in Ethiopia. A discrete choice model of household preferences for clean cooking alternatives. Energy Economics, 34, 1763-1773.

[32] J. Luzar (2007). The Political Ecology of "Forest Transition": Eucalyptus forestry in the Southern Peruvian Andes. Ethnobotany Research \& Applications, 5, 85-93.

[33] World Bank. (2019b). Electric power consumption (kWh per capita). Retrieved from https://data.worldbank.org/indicator/EG.USE.ELEC.KH.PC. 